\title{
Modern Sanatta Soyut Yaklaşımlar ve Metafizik Yönleri
}

\author{
Dr. Öğr. Üyesi Mehmet Şah MALTAŞ \\ Yıldı Teknik Üniversitesi \\ Sanat ve Tasarım Fakültesi, Sanat Bölümü \\ mehmetsah.maltas@gmail.com \\ ORCID: 0000-0002-2083-6142
}

\begin{abstract}
Öz
Modern dönemde, Bilim ve Felsefe'de olduğu gibi Sanat'ta da soyut yaklaşımlar öne çıkmaya başlamıştır. Resim sanatına müzik sanatının 'model alınması' da müziğin resme kıyasla çok daha soyut ve matematiksel bir yapısının olmasından kaynaklıydı. Resim sanatının dünyanın bir kesitinin 'aynası', bir kişinin portresi gibi belli şeylerin temsillerinin hizmetinden kurtarılarak 'saflaştırıması' ve böylece onun 'bağımsız bir sanat' haline dönüştürülmesinin çabası özellikle Kübizm ile başladığı söylenebilir. Kübist sanatçılar Rönesans'tan beri süregelmiş geleneksel tek bakış açlı optik yaklaşımı terk ederler ve duyusal olmaktan çok ussal eserler sunarlar. Dolayısıyla optik yaklaşım yerini daha zihinsel bir yaklaşıma terk eder. Bu bağlamda Apollinaire Kübizm için 'bir kavrayış sanatı' ifadesini kullanır. Tuvalin yüzeyi 'dünyaya açılan bir pencere' olmaktan çıkartılarak, yüzey artık daha çok, sanatçının zihinsel-kavramsal faaliyetinin yansıtıldığı bir alana dönüştürülür. Tuvalin yüzeyinde söz konusu olan 'imgeler' ve bütünsel olarak kompozisyon kendi iç yapısındaki ilişkiler bağlamında ele alınıp çözümlenmeye çalışıır. Yani bir resmi oluşturan bütün elemanların (renk, çizgi, şekil vs.) birbirleri ile ve yüzey ile bağıntıları ele alınır. Böylece Modern Sanatta daha dilsel ve mantıksal bir yaklaşım öne çıkmaya başlar. Dolayısıyla sanat alanında metafizik çabaların da böylece öne çıktığını söyleyebiliriz. Bu bağlamda Modern Sanattaki soyut yaklaşımlar ve bunların metafizik yönleri bu makalede tarihsel süreci bağlamında irdelenecektir.
\end{abstract}

Anahtar Kelimeler: modern sanat, resim, soyut, mantık, matematik, metafizik 


\title{
$\operatorname{arts}=$
}

Research Article

\section{Abstraction and It's Metaphysical Aspects in Modern Art}

\begin{abstract}
In the modern era, abstract approaches have come to the fore in Art as well as in Science and Philosophy. The "modeling" of music for painting was due to the fact that music has a much more abstract and mathematical structure compared to painting. It can be said that the effort for freeing the art of painting from being mere servant of representations of someone's portrait or a mirror of a fragment of the world and so purifying it, and transforming it into an independent art, particularly get started with Cubism. Cubist artists offered more rational art works then sensory, by leaving the traditional single point view approaches which continued since renaissance. Consequently optical approach leaves it's space to more mental one. In this point of view Apollinaire uses 'an art of understanding' statement for Cubism. The surface of a canvas (a painting) were not considering 'as an open window on the world' anymore, but transformed into a field which artist reflects his/her mental-conceptual activities on it. The images and the composition as a whole which appears on the surface of a canvas were becoming analyzed according their interrelationships. That is to say the whole elements which constitute a painting (color, line, shape, etc.) were becoming hold by their interrelations and their relation to the surface. Therefore in art Modern Art arena, more logical and linguistic approaches came forward. In this point of view we are able to declare that Metaphysical approaches come forward in the art field. According to this concept, abstract approaches in Modern Art and its' metapysical aspects is going to be analyzed in this article in historical process.
\end{abstract}

Keywords: modern art, painting, abstract, logic, mathematics, methaphysics 


\section{arts $s$}

\section{Gíriş'}

Modern Sanatta daha soyut ve düşünsel bir tavrın ağır bastığı söylenebilir. Katı natüralist sanatsal yaklaşımların eleştirildiği ve daha düşünsel ve ruhsal olanın vurgulandığı bir dönem olduğu sanatçıların ve eleştirmenlerin manifestolarından da açıkça anlaşılabilir.

Modern Sanatı anlamak için Rönesans'tan Modern döneme uzanan süreçteki sanat anlayışlarını da dikkate almak gerekir. Bu nedenle özellikle Rönesans sanatına değinilmiş ve sonrasında da ortaya çıkan bazı yeni yaklaşımlar ele alınmıştır. Böylece Modern Sanatta öne çıkan soyut yaklaşımlar ve bu yaklaşımların metafizik boyutlarının anlaşılması için gerekli düşünsel altyapı oluşturulmaya çalışılmıştır.

'Göz ve Tin' adlı kitabında Merleau Ponty, 'Resmin bütün modern tarihinin, kendini yanılsamacılıktan kurtarmak ve öz boyutlarını kazanmak için bütün çabalarının metafizik bir anlamı vardır' der. Modern Resim' de öne çıkan soyutlama ve soyut yaklaşımlar metafizik anlama yönelik çabalar olarak değerlendirilebilir. Ponty, Modern sanatçıların (ressamların) 'bakışını' şöyle ifade eder: Ressamın bakışı, dışa yönelen bir bakış, dünyayla yalnızca bir " fizik-optik" ilişkisi değildir artık. Dünya, temsil yoluyla ressamın karşısında değildir artık: Aslında, sanki görünürün yoğunlaşması ve kendine ulaşması yoluylaymışcasına, ressamdır şeyler içinde doğan..." (Ponty, 2006, s. 61, 66).

Ponty Rönesans'ın katı natüralist yaklaşımını eleştirir ve 'görüş'ü ve bu bağlamda algıyı ve elbetteki sanatsal faaliyeti salt optik ve dışsal olanın bir yansıması olarak değil, belki de tam tersine ruhsal olanın adete şeylere, dışa nüfuz ettiği ve böylece görüşün gerçekleştiğini ifade eder. Bu yaklaşım Rönesans'ın 'bakış' ve 'görüş' anlayışından bambaşkadır.

Bu makalede Modern sanat akımlarının dayandıkları temel düşünceler -ki daha çok sanat manifestoları üzerinden- irdelenerek Modern Sanat'ta daha soyut bir sanat anlayışına sanatçıları yönlendiren etkenlere değinilmiştir. Söz konusu etkenler ile modern (yeni) yaklaşımlar daha önceden yüzyıllarca süregelen sanat

1 Bu makalenin temel fikri yazarı tarafından 18-20 Ekim 2018 tarihlerinde yapılan VAN YÜZÜNCÜ YIL ÜNIVERSiTESi GÜZEL SANATLAR FAKÜLTESI ULUSLARARASI KÜLTÜR, SANAT VE TOPLUM SEMPOZYUMU'nda sunulan bildirisine dayanmaktadır (www.cassymposiumvan.com). 
anlayışından temelde farklıık gösterdiği tespit edilmiştir. Makalede bu temel farklar üzerinde durulmuştur.

Sanat alanında ortaya çıkan yeni soyut yaklaşımların Bilim, Felsefe, Mantık ve Matematik alanlarında da neredeyse eşzamanlı ortaya çıktığı söylenebilir. Bu bakımdan hem sanat hem de diğer alanlarda daha dilsel ve kavramsal yaklaşımlar öne çıkmıştır.

Bu makalede öncelikle Modern Sanat'ta ortaya çıkan yaklaşımların ardındaki bazı koşullar üzerinde durulmuş ve özellikle Kübizm akımı üzerinde durulmuş ve Kübizm ile bağ kurmuş bazı sanatçıların sanata daha soyut yaklaşımları ele alınmıştır. Ayrıca tamamen soyut bir sanat anlayışı benimseyen bazı sanatçıların fikirleri bağlamında Modern Sanat ele alınmıştır. Özellikle o dönemin sanatçıları ve sanat eleştirmenleri tarafında yayımlanan metinler, bildiriler ve kitaplar referans alınmıştır.

\section{Rönesans'tan Modern Döneme Uzanan Süreçte Sanatta Matematiksel Yaklaşımlar Ve Modern Sanatın Doğmasındaki Etkenler}

Fransızca telaffuzuna göre Türkçe'de yer alan 'Rönesans' terimi 'yeniden doğuş' anlamındadır. Terim, 'Rönesans' (terimin İtalyanca'sı 'Rinascimento'dur) olarak adlandırılan uzun bir dönemi (genel olarak 14 ile 16. yüzyıllar arası dönemi) ifade için daha sonradan tarihçiler ve sanat tarihçileri (Vasari ve Burckhardt gibi) tarafından kullanılmıştır. Yeni bir dünya görüşü bununla birlikte yeni bir sanat anlayışı İtalya merkezli olmak üzere Avrupanın tümüne yayılmıştır.

Rönesans sanatının doğuşunda önemli bir referans olarak sıkça Giotto di Bondone'den söz edilmektedir. Hatta bazı sanat tarihçileri Rönesans için onu temel bir referans olarak ele alırlar. Giotto, resim sanatına, "optik biçim" " yaklaşımını 'sokarak' sanatta natüralist bir anlayışın önünü yeniden açmıştır. Onun resimlerinde henüz 'mekanın' bir sistem olarak tasvir edilmesinin (figürasyonunun) matematiksel yöntemi söz konusu değildi. Bu yöntem iki kuşak sonra 'icat' edilmişti. Ançak Giotto'nun çalışmalarındaki sözü edilen yaklaşımı, ona götüren yolda önemli bir adım olarak da değerlendirilebilir (Maltaş, 2019, s.224-225). 


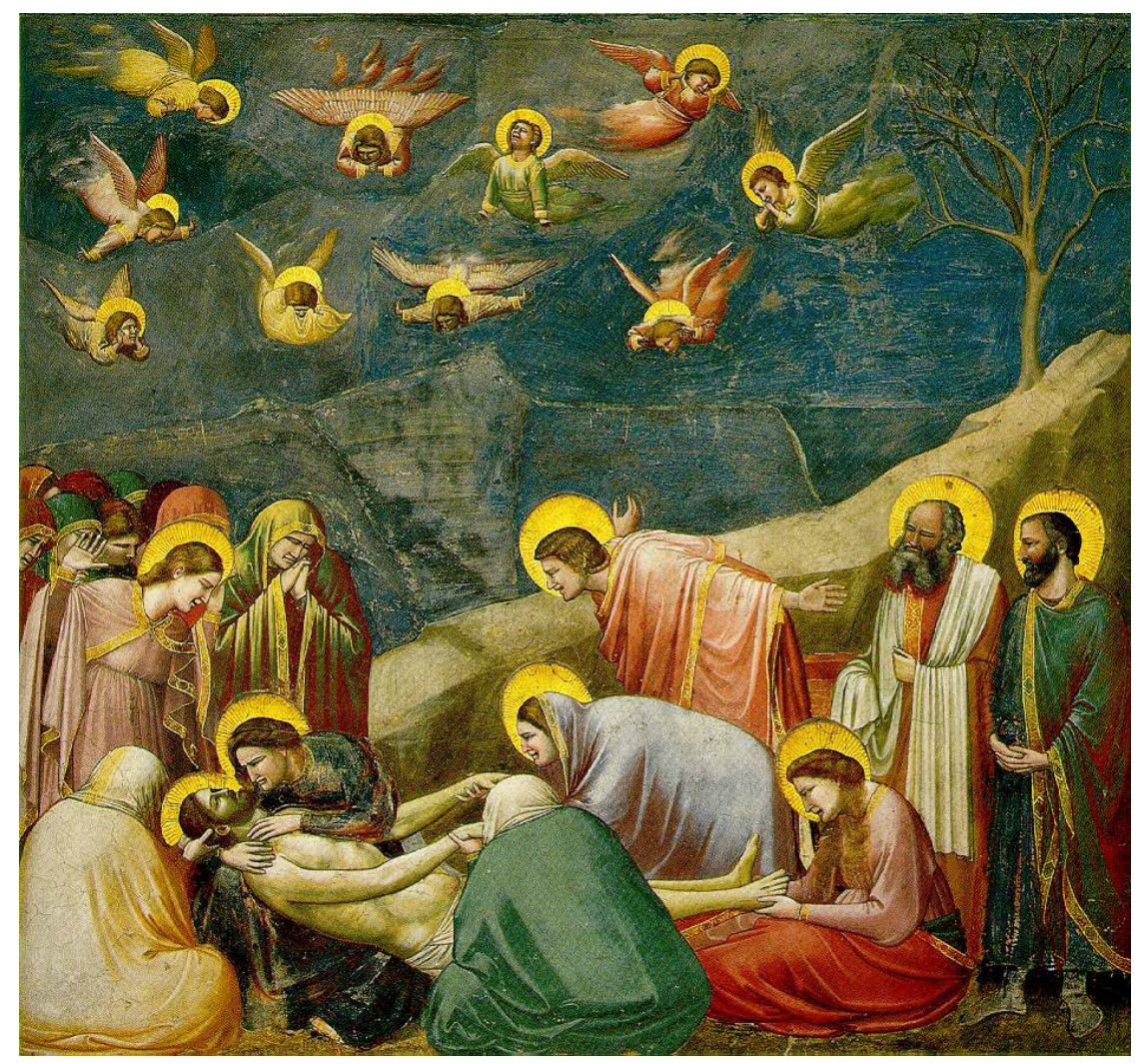

Görsel 1. Giotto di Bondone, Ağıt, 200 x 185 cm, Fresko, c.1304 - c.1306, Capella degli Scrovegni, Padua, Italya

Sanatta matematiksel yaklaşım Rönesans'ta ve Antik dönemlerde de söz konusudur. Ama modern dönemde bu yaklaşım daha da soyut bir hal almıştır. Matematiksel yaklaşım Antik Yunan felsefesinde de önemli bir yere sahiptir. Pisagor (Pytagoras) ve Pisagorcular'ın (başta Platon sayılabilir) evrene dair, sayısal ve oransal ilişkiler bağlamında açıklamaları vardır. Platon, Timaios adlı kitabında "Evren, orantı vasıtasıyla uyum içinde meydana getirilmiştir" (The Timaeus of Plato, s. 99) der ve evrenin biçimlenmesine yönelik açıklamasını 'matematiksel bir zemin' üzerinde yapar.

Antik Roma döneminin mimarlarından ve mimari kuramcılarından olan Vitruvius Mimarlık Üzerine On Kitap adlı eserinde, mimari'yi bir insan bedenindeki ("fiziği düzgün bir erkek") oransal ilişkiler üzerinden ele alır.

Rönesans'ın sanat kuramcılarından ve Doğrusal (Linear) Perspektif'in de ilk kuramcısı olan Leon Battista Alberti (1404-1472), Resim Üzerine adlı kitabında "Eğer 
şimdiye kadar duyulmadık ve görülmedik sanatları ve bilimleri, herhangi bir öğretmen ve örnek alacağımız bir model olmadan keşfedebiliyorsak, bizim şöhretimiz daha da büyük olmalıdı" (Alberti, 1991, s. 34) der. Kendisinin ve bazı çağdaşlarının (başta Brunelleschi olmak üzere Donatello, Nencio, Luca, Masaccio, gibi) iddiası olan 'yeni bir sanat' (anlayışı-kavrayışı) söz konusudur. Bu konu ile ilgili bir başka ifadesi: "'Pliny gibi bir resim sanatı tarihi yazmadığımıza göre biz sanata tamamen yeni bir yoldan/ yönden yaklaşıyoruz" (A.g.e., 62). Burada belirtilen "tamamen yeni bir yoldan yaklaşım' kısaca matematiksel bir yaklaşım olarak ifade edilebilir.

Alberti'nin yukarıda aktarılan sözlerinde değindiği yeni yaklaşımı, Floransa ve Bağdat adlı kitabında Belting ise şöyle yorumlar: "Alberti'nin ders kitabını, ressam olmadıkları halde bu ikisine (mimar Filippo ve Donatello) ithaf ettiğine bakılırsa, asıl derdinin "matematik içerikli yeni bir sanat (arte)" olduğu anlaşılır" (Belting, 2012, s. 169).

Rönesans'ın sanatı her ne kadar matematik içerikli yeni bir sanat olsa da, bu, soyut anlamda bir sanat olmaktan henüz çok uzaktır. Ancak 'matematik içerikli yaklaşım', sanata daha soyut yaklaşım yolunda son derece önemlidir.

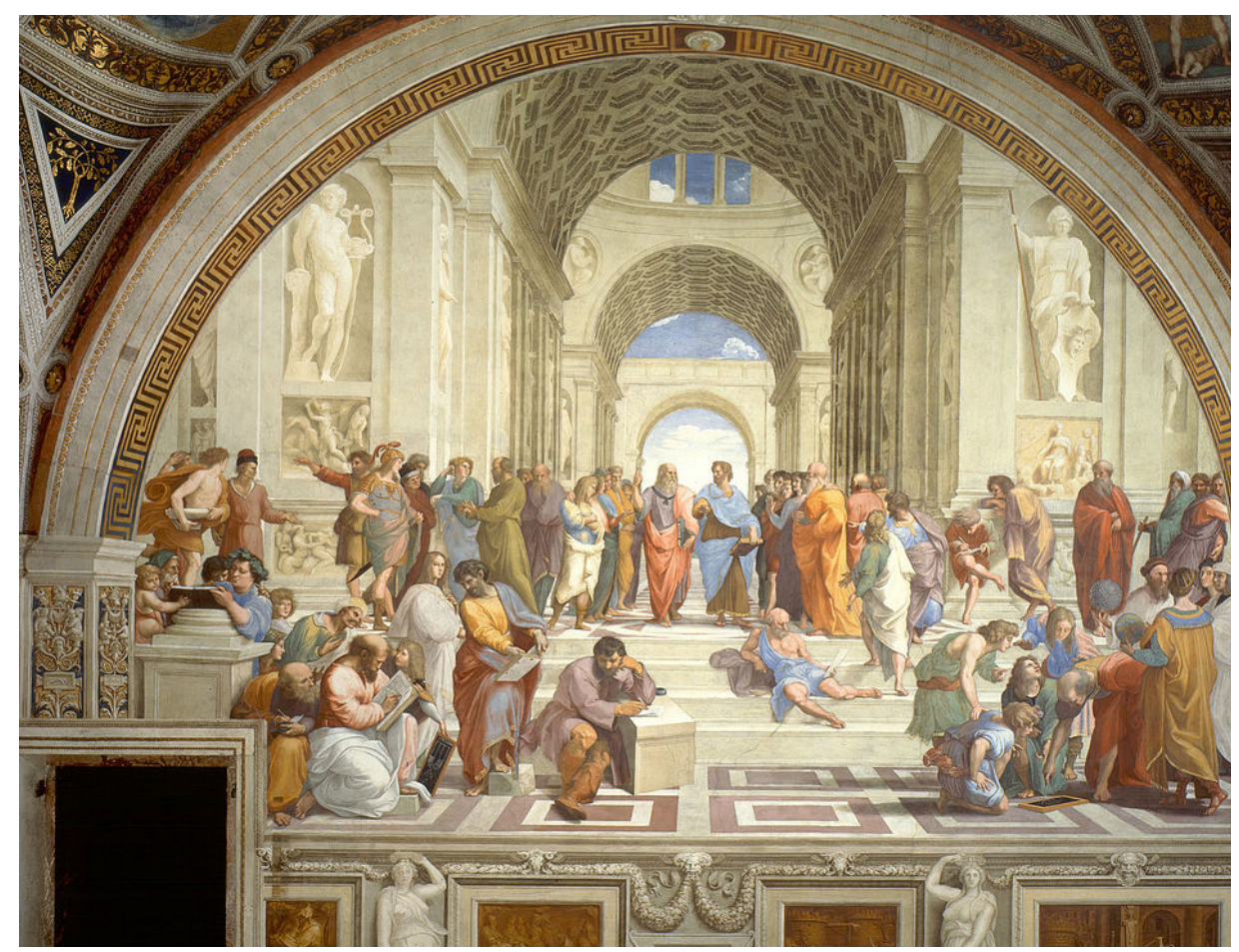

Görsel 2. Raffaello Sanzio, Atina Okulu, $500 \mathrm{~cm} \times 770 \mathrm{~cm}$, Duvar üzerine Fresko, 1509-1511, Vatikan, Roma, italya 


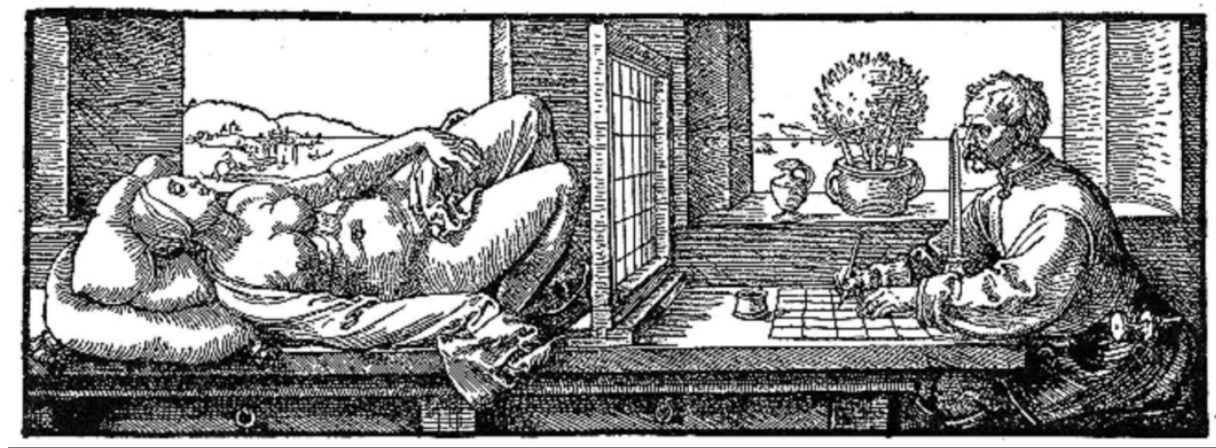

Görsel 3. Albert Dürer, Perspektif Dersi, Ahşap baskı, 1525-1527

Perspektifle birlikte Rönesans, görme koşullarını herkes için anlaşılır kılmayı ve resimlerle ortaya koymayı amaçlayan yeni bir resim pratiğinin donanımını geri kazandırdı. Bu yüzden Rönesans' ta sanat uygulamalı bilim olarak görülüyordu ve optik ile sanat arasında, ancak Kepler'in dönemimde feshedilen bir ittifak kurulmuştu (Belting, 2012, s. 34-35).

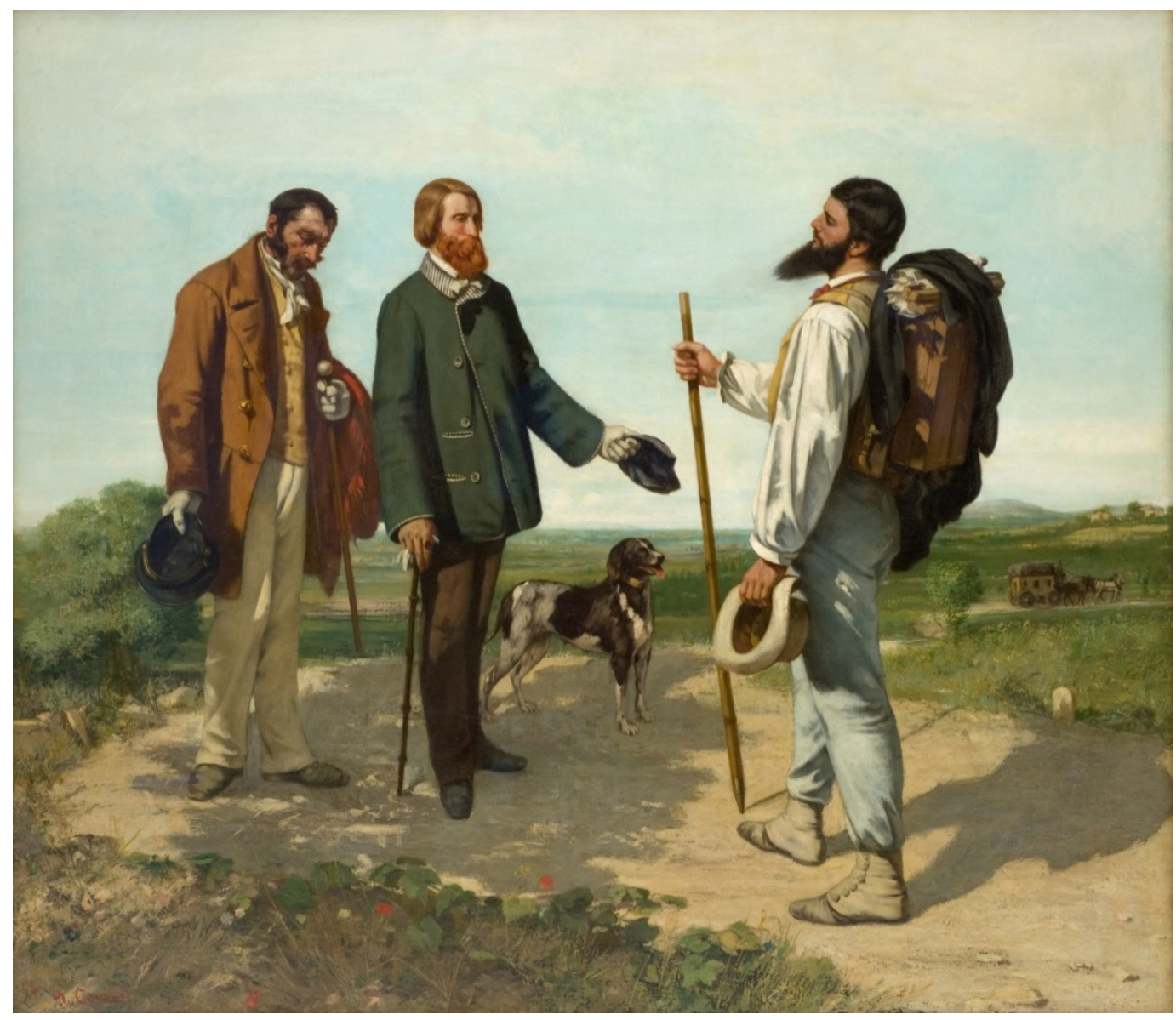

Görsel 4. Gustave Courbet, 'Günaydın Courbet bey', $129 \mathrm{~cm} \times 149 \mathrm{~cm}$, Tuval üzerine yağlıboya, 1854, Fabre Müzesi, Fransa

19. yüzyılın önemli Fransız şairi ve sanat eleştirmeni Baudelaire, 'Modern 
Hayatın Ressamı' adlı kitabının Modernite başlıklı kısmında 'saf sanat', 'mantık' ve 'genel yöntem'e dikkati çeker ve insanın 'vücuda gelme' halinin sanatta özgünlük açısından önemine vurguda bulunur:

Antik sanattan saf sanat, mantık, genel yöntem dışında kalan şeyleri öğrenmeye çalışanın vay haline! Oraya fazla gömülünce şimdi'ye ilişkin belleğini yitirir; içinde yaşadığı koşulların sağladığı haklardan ve ayrıcalıklardan vazgeçer. Burada gerçekten bir ayrıcalık söz konusudur, çünkü neredeyse bütün özgünlüğümüz, zamanın duyularımıza vurduğu damgadan kaynaklanır (Baudelaire, 2003, s. 107).

X ışınlarının (röntgen) keşfinden, motorlu araçların gelişimine kadarki bilim ve teknik alandaki gelişmeler dünyayı çok farklı açılardan da algılama olanağını sağlamıştır. Modern Sanat'ın önemli isimlerinden Fernard Leger 1914 yılında "eğer resimsel ifade değişmişse bunu modern yaşam zorunlu kılmışıı" (Moszynska, 2004, s. 8) şeklinde ifade eder. Sanatçılar kendi sanatları vasıtasıyla dünyaya artık farklı bir şekilde 'muhatap' olma yollarını bulmaya çaba gösterdiler. Modern dönemde Kübizm bu çabanın en önemli sanatsal ifadesi olarak ele alınabilir.

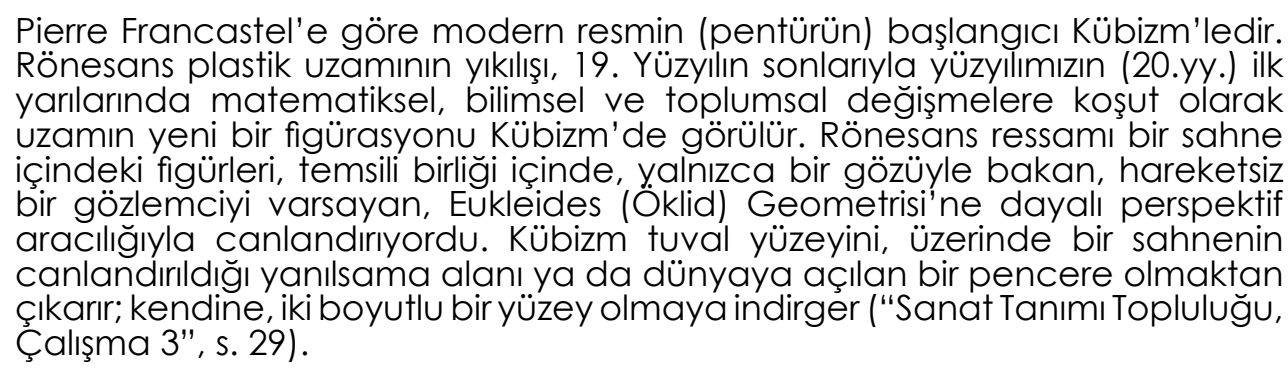

Kübistler resimsel elemanlar olarak yüzey, çizgi ve renk gibi unsurları ilk defa daha bağımsı bir şekilde, yani geleneksel perspektifin ötesine geçerek daha zihinsel-kavramsal ilişkiler içerisinde ele aldılar. Cezanne'nin açtığı yolda daha ileri giden Kübistler özelde resim sanatında genelde de sanatta devrimsel bir dönüşümü gerçekleştirmişlerdir. Gabo "Sanatta Konstrüktif Düşünce" adlı makalesinde "Bu ekolün sanatçılarının zihinlerinde yarattığı devrim, sadece aynı dönemde fizik dünyasında yaşanan devrimle kıyaslanabilir" diyerek Kübizm'in önemini vurgular. 


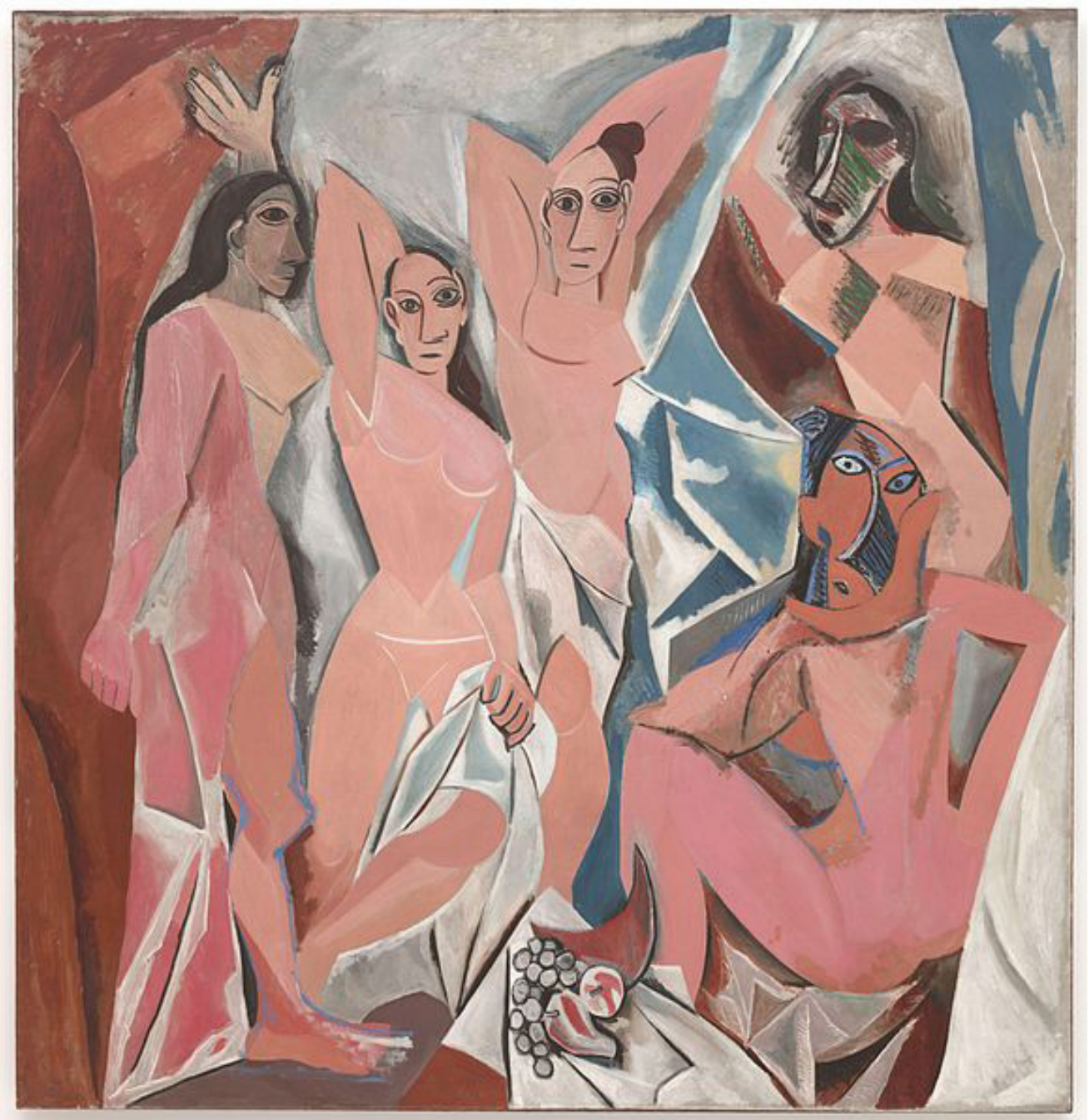

Görsel 5. Pablo Picasso, Avignon'lu Kızlar, Tuval üzerine yağlıboya, 244 x 235 cm., 1907, New York MoMA, A.B.D.

\section{Modern Sanatta Soyutlama Ve Soyut Anlayış}

19 yüzyılda fotoğraf makinesi ile elde edilen görüntülerin basılabilmesi ile birlikte, Rönesans'tan beri süregelen resmin 'dünyaya açılan bir pencere' olması görüşü, daha kökten sorgulanmaya başlandı. Sanatçılar resim sanatının temel özelliklerini yeniden sorgulamaya yöneldiler. Bu bağlamda Lynton, Maurice Denis'in 1890'da yayımlanan denemesinin ilk cümlesini aktarıp yorumlar:

Unutmayın ki bir resim -bir savaş atı, çılak bir kadın ya da herhangi bir öykü olmaktan önce- üstü renklerle belli bir düzene göre boyanmış düz bir yüzeydir.' Bu görüş üç boyutlu gövdelerin boşluğa yerleştirilmesi ilkesine dayanan Rönesans resim anlayışının sonunu haber verdiği gibi, soyut sanata bir çağrı olarak da yorumlanıyordu (Lynton, 1982, s. 17-18). 


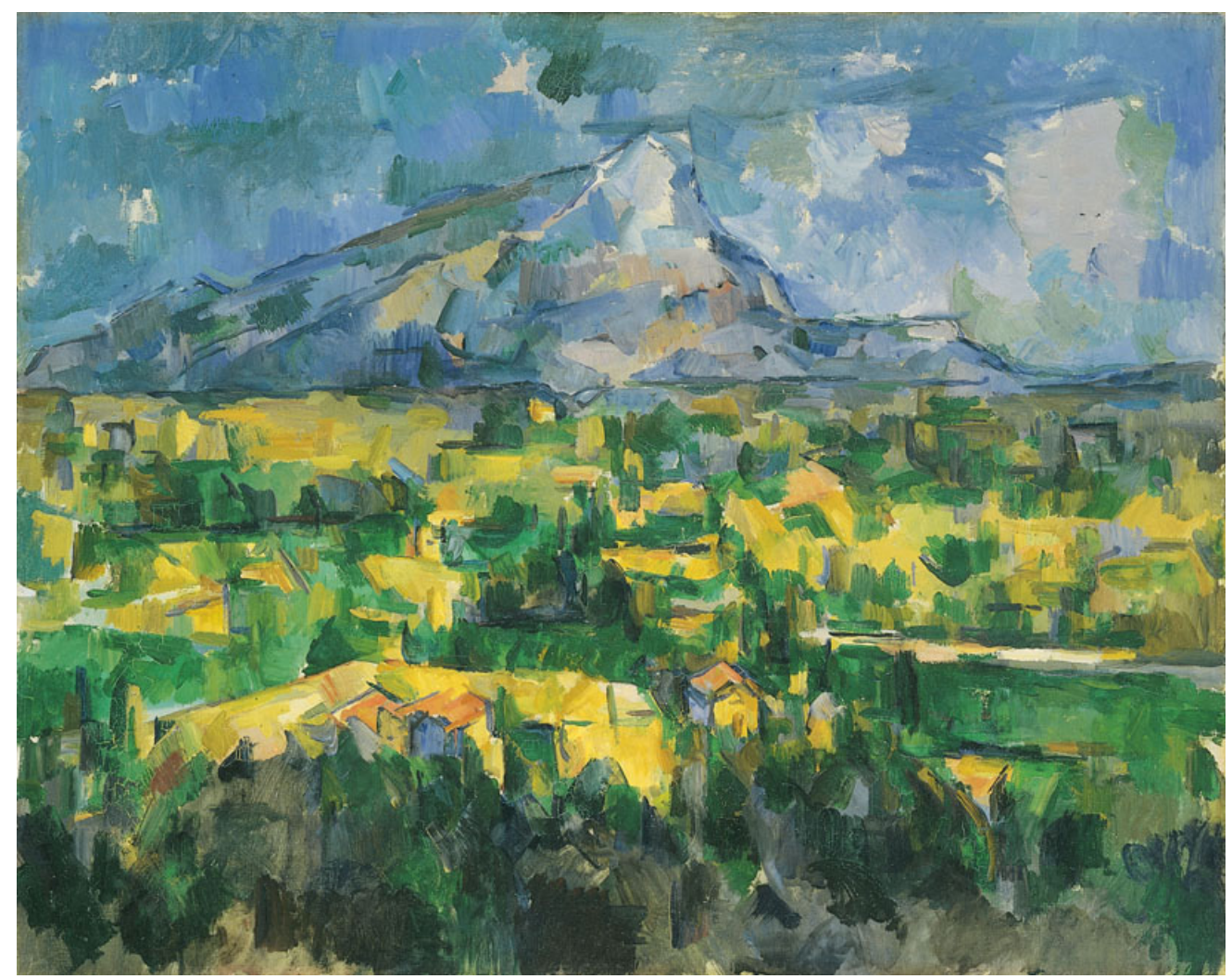

Görsel 6. Paul Cezanne, Mont Sainte-Victoire, 73 x $91 \mathrm{~cm}$, Tuval üzerine yağlı boya, 1902-04, Philadelphia Museum of Art, A.B.D.

19. yüzyılın ortalarından itibaren sanatçıların, daha önce yapılan resim konuları hiyerarşisini de artık pek önemsemedikleri yaptıkları çalışmalardan anlaşılmaktadır. Daha önceleri en üst düzeyde görülen tarihi ve dini konuları ele alan resimler yapmak yerine gündelik yaşam sahneleri, manzara ve natürmort gibi konulara sanatçıların daha çok yöneldikleri görülmektedir. "Post Empresyonistler yirminci yüzyıl sanatı için hem kuramsal düzeyde, hem de uygulamada birçok başlangıç noktaları sağladılar" (A.g.e., s. 19). Özellikle Cezanne'nın etkisi başta Kübistler üzerinde olmak üzere çok güçlü olmuştur. Cezanne, bir dönem Paris'ten uzak bir yerde ve âdete inzivaya çekilerek resim sanatını ve geleneksel perspektif anlayışını sorgulamıştır. Kendi görüşleri bazı çağdaşlarını ve sonraki kuşağın bazı sanatçılarını da derinden etkilemiştir. Emile Bernard'ın Cezanne Üzerine Anılar adlı kitabında Cezanne ile arasındaki bir diyalog bu bağlamda gayet önemlidir:

"-Descartes felsefeye nasıl yeniden başlamışsa, siz de sanata sıfırdan başlamak istediniz sanıyorum. Sizden öncekilere bir daha dönüp bakmak istemiyorsunuz şimdi. 
-Evet, yeni bir sanatın ilk başlayanı olmak isterim ben. Sanııı şimdi benim arkamdan gelenler olacaktır" (Bernard, 2001, s. 87).

Bu diyalogdan da anlaşılacağı üzere Cezanne resim sanatında yeni bir yaklaşımı-görüşü ortaya koyma çabası içerindeydi. Resim sanatında geometrik figürler üzerinde yoğunlaşmaya öncelik verilerek, koni, küp, silindir ve küreye dönüştürme yönünde çabaların geliştirilmesi önerisinde bulunur ve ancak nesnelerin görüntülerinin bu temel formlara indirgenmesinden sonra resim yapma alışkanlığının edinilmiş olacağını söyler (A.g.e., s. 91).

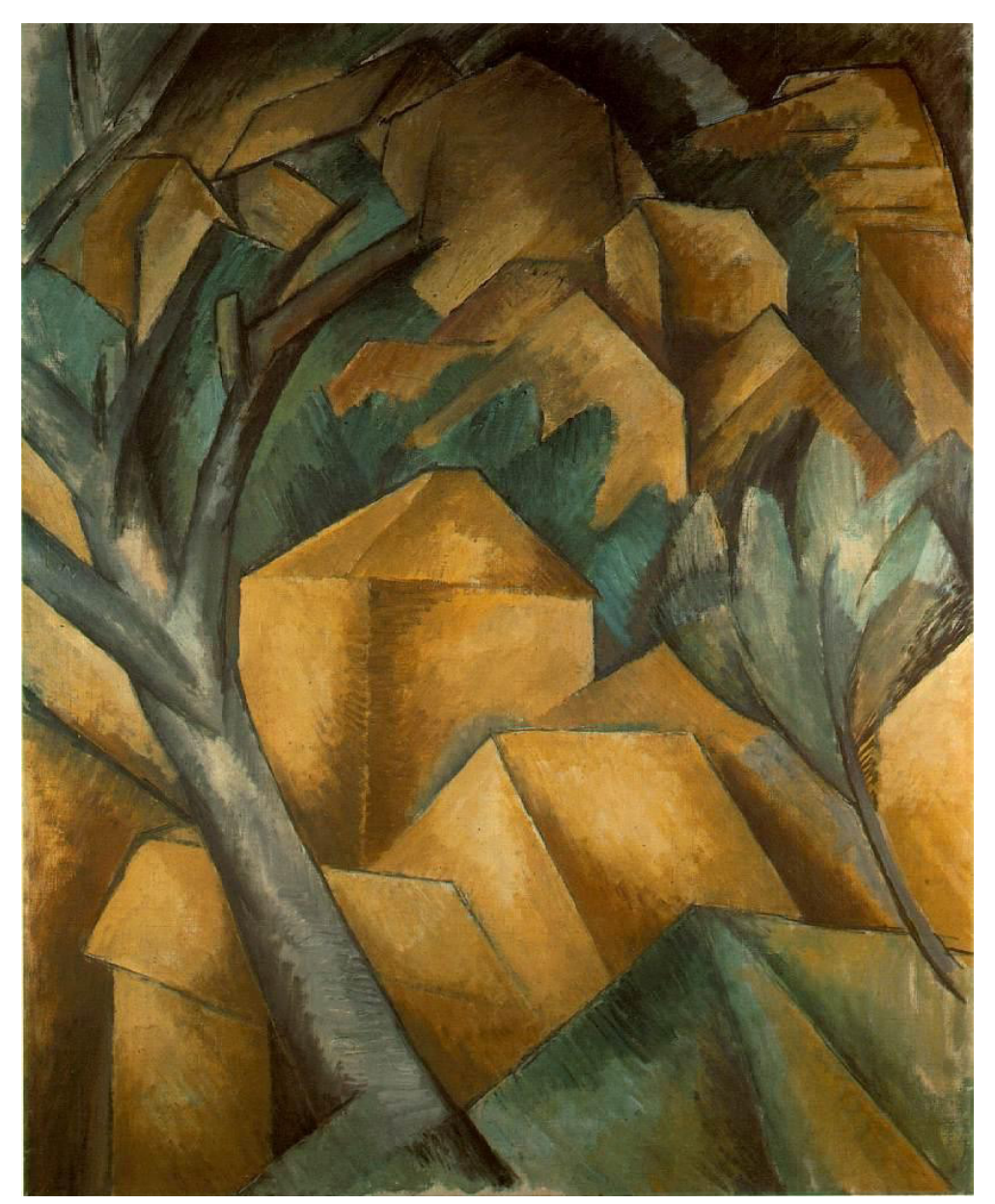

Görsel 7. Geoges Braque, Houses at L'Estaque 1908, Tuval üzerine yağlı boya, 73 x 60cm, Kunstmuseum, Bern, İsviçre

Kübizm'in savunucularından şair, yazar ve sanat eleştirmeni Guillaume Apollinaire, Modern Resimde Konu Üzerine adlı makalesinde 'saf resim' tabirini kullanır. Kübist ressamların artık doğayı natüralist bir anlayışla taklit etmekten 
kaçındıklarını ve saf resimsel bir anlayışa doğru yöneldiklerini belirterek, onların resim kompozisyonu bağlamında saf plastik unsurlar arası ilişkiyi ve kontrastı önemsediklerini vurgular. Saf plastik unsurların ilişkisinden doğan bir ahenkten de yüksek derecede estetik zevk alınabileceğini Plinius'tan aktardığı bir hikâye ile destekler ve ardında da Avangard ekolün genç ressamlarının saf resim yapmak istediklerini ve bunun tümüyle yeni bir plastik sanat olduğunu belirtir: "Avangard ekollerin genç ressamları da, saf resim yapmak istiyor. Onlarınki tümüyle yeni bir plastik sanat. Daha başlangıcında, ve daha olabileceği kadar soyut değil. Yeni ressamlar bir bakıma farkında olmadan matematikçi, ama doğayı terk etmemişler ve onu sabırla inceliyorlar" (Sanat ve Kuram, 2011, s. 214). Bu ifadelerinden de anlaşlacağı üzere Apollinaire yeni bir plastik sanat olarak, saf resim ifadesi ile soyut bir sanat anlayışını kasteder ve sanatçıları saf bir sanata yönelmeleri için teşvik eder. Yani resim sanatının -daha önce geleneksel olarak geldiği gibi, doğanın çeşitli kesitlerini yansıtan veya tarihi meselelerin sahneleri veya insan portreleri olmasının hizmetinden çıkartılarak- saf plastik unsurlar olarak renk ve çizgi unsurlarının artık soyut olarak ele alındığı bir sanat haline gelmesini söz konusu eder. Yeni Resim: Sanat Notları başlıklı metinde de Apollinaire genç Kübist ressamların bize duyusal olmaktan çok ussal olan eserler sunduklarını belirtir (A.g.e., s. 215). Kübist Ressamlar'dan adlı makalesinde de "Kübizm eski resim ekollerinden bir taklit sanatı olmamasıyla değil, yaratıma yönelen bir kavrayış sanatı olmasıyla ayrıı"ı" ifadesinde bulunur (A.g.e., s. 215). Bu ifadede de dikkati çeken hususun Kübizm'i bir kavrayış sanatı olarak tabir etmesidir. Kavrayış, duyusallık'tan öte entelektüel yani zihinsel bir faaliyet olarak gerçekleşir. Apollinaire bu meseleyi Kübizm' de çeşitli eğilimleri sınıflandıııken saf eğilimlerden biri olarak nitelediği "Bilimsel Kübizm" kapsamında açıklar: "O görmenin gerçekliğinden değil, kavramanın gerçekliğinden ödünç alınan öğelerden yeni yapılar resmetme sanatı" (A.g.e., s. 216). "Gerçeklik" ve "nesne" duyusal olmaktan öte kavramsal meseleler olarak ele alınır. Kübistler için nesne artık belli bir açıdan resmedilebilen bir şey olmaktan çıkar. Nesne ancak kavramsal bütünlüğü ile "gerçekçi" bir şekilde tasvir edilebilir. Aslında Kübistler her ne kadar dış dünyayı yani fiziksel nesneler dünyasını terk etmemiş olsalar da onlar artık daha çok zihinsel olanı önemsemeye ve tuvalin yüzeyini artık bu bağlamda ele almaya başladılar. Tuvalin yüzeyini artık "optik gerçekliğin" yansıłılığı bir alan olmaktan çıkarıp bunu daha çok zihinsel faaliyetin yansıtıldığı bir alana dönüştürürler. Bu bağlamda matematik, özellikle de geometri onlar için son derece önemli bir yol gösterici olur. Onlar Öklid dışı geometrilere de ilgi göstererek bunu sanatsal ifade aracı olarak ele almaya başladılar. 


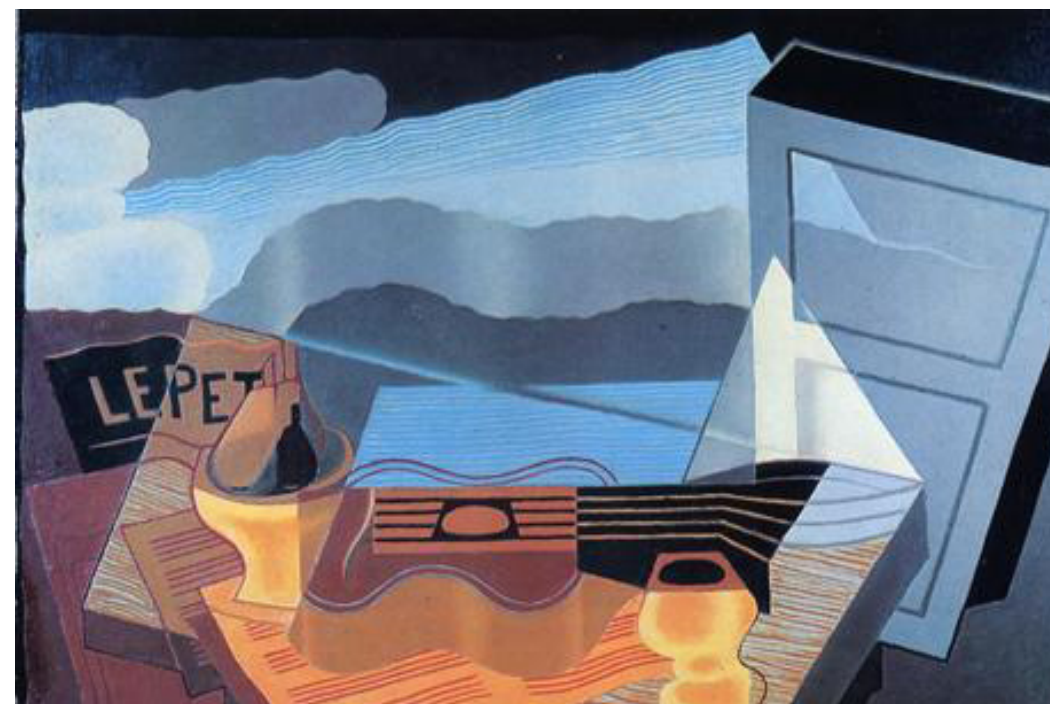

Görsel 8. Juan Gris, Körfezin Karşıındaki Manzara, 65 x 100 cm, Tuval üzerine yağlı boya, 1921, Musée National d'Art Moderne, Centre Georges Pompidou, Paris, Fransa

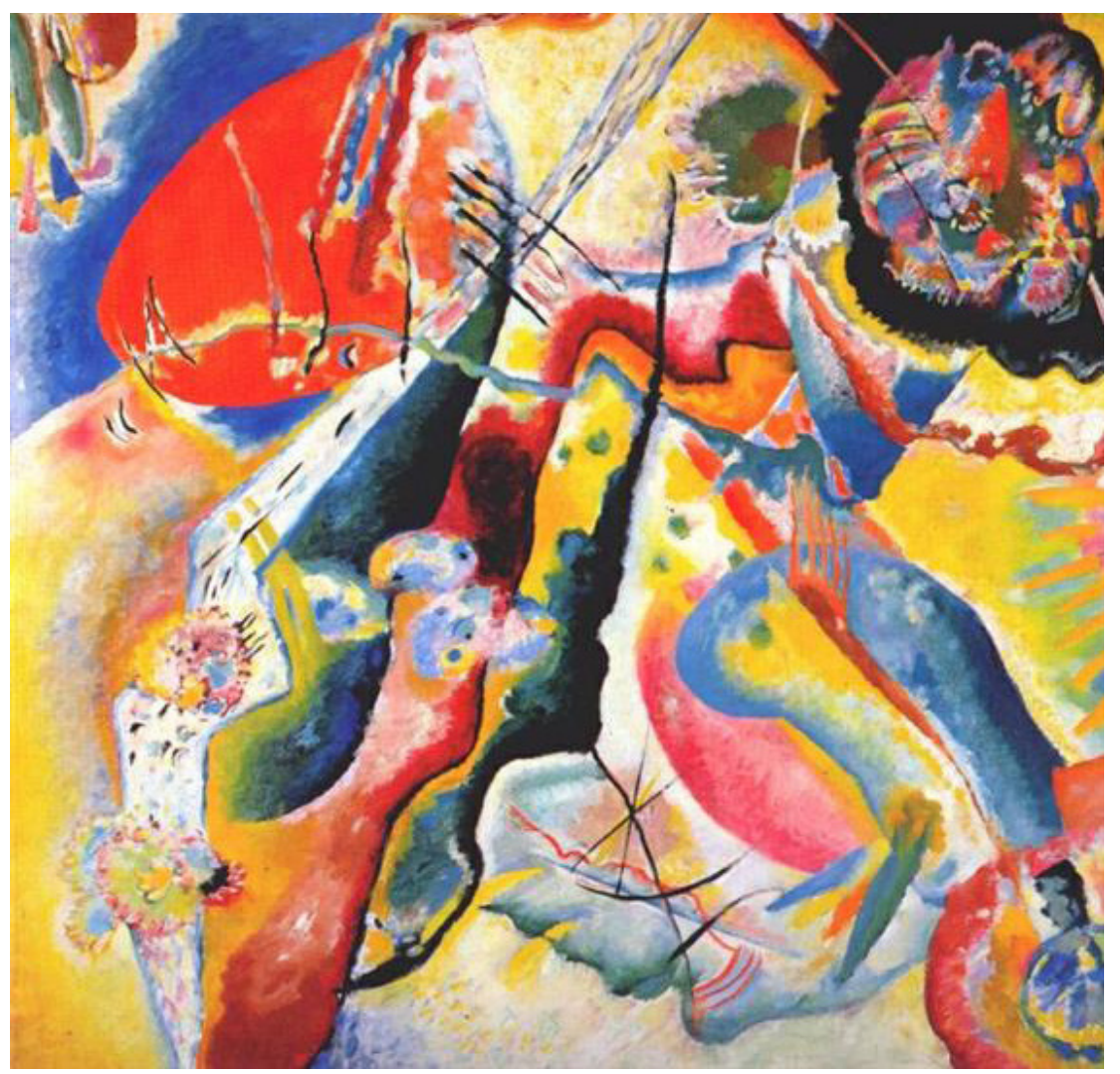

Görsel 9. Wassily Kandinsky, Kırmızı Lekeli Resim, $130 \times 130$ cm, Tuval üzerine yağlıboya, 1914, Musée National d'Art Moderne, Centre Georges Pompidou,Paris, Fransa

Soyut resim sanatının önde gelen sanatçılarından biri olan Kandinsky, Sanatta Ruhsallık Üzerine adlı kitabında özsel ve içsel olanın, başka bir deyişle ruhsal olanın 


\section{$\operatorname{arts}=$}

Önemini vurgular. Kitabın giriş kısmında:

Her sanat eseri, çağının çocuğu ve pek çok durumda duygularımızın kaynağıdır. Bundan da anlaşılacağı gibi, uygarlığın her dönemi, asla tekrarlanmayacak olan kendine özgü bir sanat meydana getirir. Geçmişin sanat ilkelerini canlandırma çabaları en fazla ölü bir sanat doğurur. Eski Yunanlılar gibi yaşamamız ve hissetmemiz olanaksızdır. Aynı şekilde, heykelde Yunan metotlarını takip etmeye çalışanlar, yalnızca bir form benzerliği elde ederler; eser sonsuza değin ruhsuz kalır. Böylesi bir taklidin, maymunun yaptığı taklitten farkı yoktur... (Kandinsky, 2001, s.35).

Açıkça anlaşılabileceği gibi Kandinsky, her bir zamanın kendi özgün ruhuna dikkati çeker ve sanatta eskiyi biçimci açıdan taklit etmeyi de içi boş ve anlamsız bulur. Ayrıca Materyalizmi tenkit eder. "Evrenin yaşamını kötü, yararsı bir oyuna çevirmiş olan materyalizm kâbusu henüz geçmiş değil; ruhun uyanışını pençesinde tutuyor. Karanlığın geniş uçurumunda yalnızca zayıf bir ışık küçük bir yıldız gibi parıldıyor..." (A.g.e., s. 36) diyerek uzun maddeci dönemin insanın ruhunu tutsak etmiş olduğunu ve bu tehlikenin henüz geçmemiş olduğunu ifade eder. Korku, neşe, keder gibi duyguları kaba bulur ve Materyalizmin pençelerinden kendini kurtaran sanatçının daha ince ve yüce duyguları verebileceği bir sanattan söz eder. Sanatta ruhsal yaşantının en önemli unsurlardan biri olduğunu belirtir. "Sanatın ait olduğu ve en kuvvetli unsurlardan biri olduğu ruhsal yaşantı, ileri ve yukarı doğru giden, karmaşık fakat ayırt edilmesi kolay ve belirgin bir harekettir. Hareket, deneyimin hareketidir. Farklı biçimler alabilir; fakat asında aynı içsel düşünce ve amaca dayanmaktadır" (A.g.e., s. 42). Ruhun yaşamını da yatay bir şekilde eşit olmayan bölümlere ayrılan bir üçgen diyagramıyla temsil edilebileceğini yazar. Bireyin ve insanlığın bedeninin onsuz sağlıklı olamayacağı ruhu, sanatın içsel hakikati olarak ifade eder. Sanatçının her türlü formu içsel intiyaç bağlamında kullanabileceğini belirtir. Sanat ve Sanatçılar adlı kısımda da şöyle bir ifadede bulunur: "Resim bir sanattır ve sanat, geçici, tek başına ve belirsiz bir üretim değildir. İnsan ruhunun geliştirilmesine ve arıtılmasına yani ruhsal üçgenin yükseltilmesine yöneltilmesi gereken bir güce sahiptir" (A.g.e., s. 134). Bu ifade ile sanatın asıl işlevinin, insan ruhunun geliştirilmesi ve arıtımasına yönelik olduğunu söyler. 


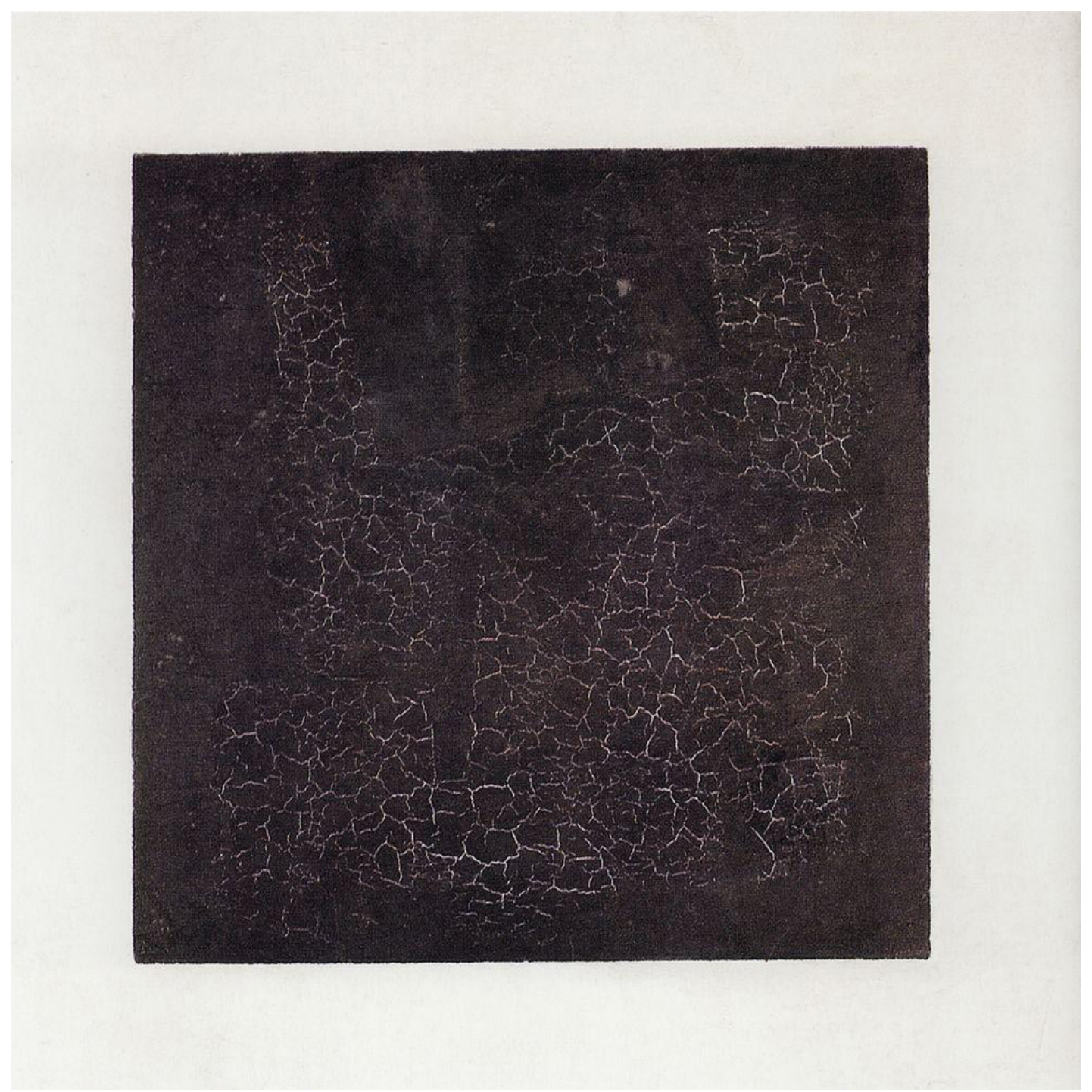

Görsel 10. Kazimir Malevich, Siyah Kare, $106 \times 106$ cm, Tuval üzerine yağlıboya, 1915, Galeri Tretyakov, Moskova, Rusya

Modern dönemin en avangard sanatçılarından biri olan Malevich'in, Kübizm ve Fütürizmden Süprematizme: Resimde Yeni Gerçekçilik adlı sanat manifestosu, "Ancak resimlerde doğanın küçük köşelerini, madonnaları ve arsız Venüsleri görme alışkanlığına sahip zihnin ortadan kaybolmasından sonra, saf, canlı bir sanat eserine tanık olacağız" (Sanat ve Kuram, 2011, s. 199) ifadesi ile başlar. Bu manifestoda adeta batı resim sanat tarihinin de çok kısa bir eleştirel özeti ile Fovistleri, Kübistleri ve Fütüristleri de eleştirerek Süprematizm olarak adlandırdığı ve bunu "saf resim sanatı" olarak tabir ettiği kendi sanat anlayışını ortaya koyar. Saf resim sanatından ne kastettiğini de içinde bu tabiri kullandığı cümleden önceki bir iki cümlede açıklar: "...Ve renk resmin yaşamasını sağlayan şeydir, yani en önemli şeydir." Ifadesi ve 
"Ve burada ben saf renk biçimlerine (formlarına) vardım." Ayrıca bu bağlamda sanatçılara şöyle bir tavsiyede bulunur: "Saf ressam olmak istiyorlarsa ressamların konuyu ve nesneleri bırakmaları gerekiyor" (A.g.e., s. 206). Bu bağlamda ressamların konuyu ve nesneleri bırakmaları saf plastik resmin bir talebi olarak söz konusu edilmektedir. Bu talebi tam olarak ne Fovistler ne Kübistler ne de Fütüristler yerine getirmediği için onları da eleştirir. Ancak onların çabalarını da saf resim sanatına ulaşma açısından önemser. Kübistlerin nesneyi, özü, amacı, duygusu ya da temsilinin tamlığıyla birlikte düşünme ve ele alma girişimlerini gereksiz bulur. Bir resmin yapılır olduğunu ama nesnenin (yukarıda belirtilen anlamda) aktarılamaz olduğunu iddia eder. Böylece resim sanatını yapısal anlamda söz konusu eder. Renk ve form' $u$ da sanatçının saf yaratma çabasının aracı olarak bağımsız ve canlı unsurları olarak görür ve bu bağlamda bu anlayışı da resimde saf yeni gerçekçilik olarak öne sürer. Malevich'in bu yakıaşımını kendi çağdaşı bazı başka sanatçılar da benimser. Örneğin El Lissitszky, The van Doesburg vd. gibi.

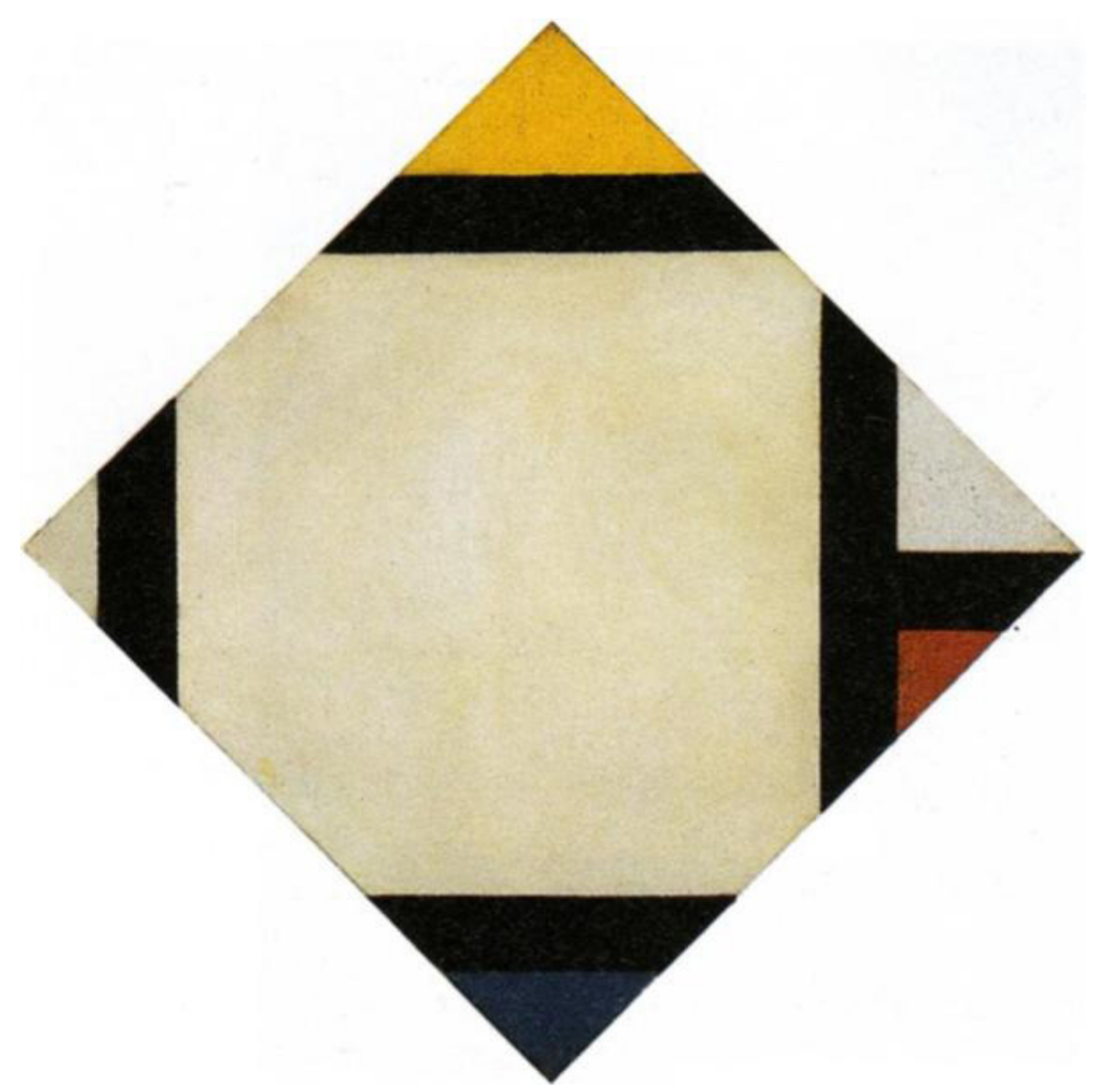

Görsel 11. Theo van Doesburg, Kontre Kompozisyon VII, $63.5 \times 64 \mathrm{~cm}$, Tuval üzerine yağlıboya, 1924, Özel Koleksiyon 


\section{arts}

Tamamen soyut bir anlayışı öne süren De Stijl grubunun önde gelen sanatçısı Theo van Doesburg, Neo Plastik Sanatın Illkeleri adlı metninde "...Görsel sanatın gelişebileceği ve kullanılabileceği tek yol biçim verici araçları yeniden değerlendirmek ve arındırmaktan geçer. Kollar, bacaklar, ağaçlar ve manzaralar tartışmasız bir şekilde ressama has araçlar değildir. Ressamca araçlar şunlardır: renkler, biçimler, çizgiler ve düzlemler" ifadesinde bulunur (Sanat ve Kuram, 2011 , s. 316). Doesburg görsel sanatlar için renk, çizgi ve düzlem gibi unsurların saf bir şekilde ele alınmasını görsel sanatların gelişimi için asıl bir koşul olarak öne sürer. Saf sanatsal araçlar ile sanatsal dengenin elde edilmesi ve böylece biçimci bir uyumun yaratılması. Sanatçı artık düşüncesine, doğrudan elindeki asıl araçlarla biçim verir. "Sanat eseri bağımsız, sanatsal açıdan canlı (plastik) bir organizma, içinde her şeyin başka her şeyi dengelediği bir organizma olur" (A.g.e., s. 317) der.

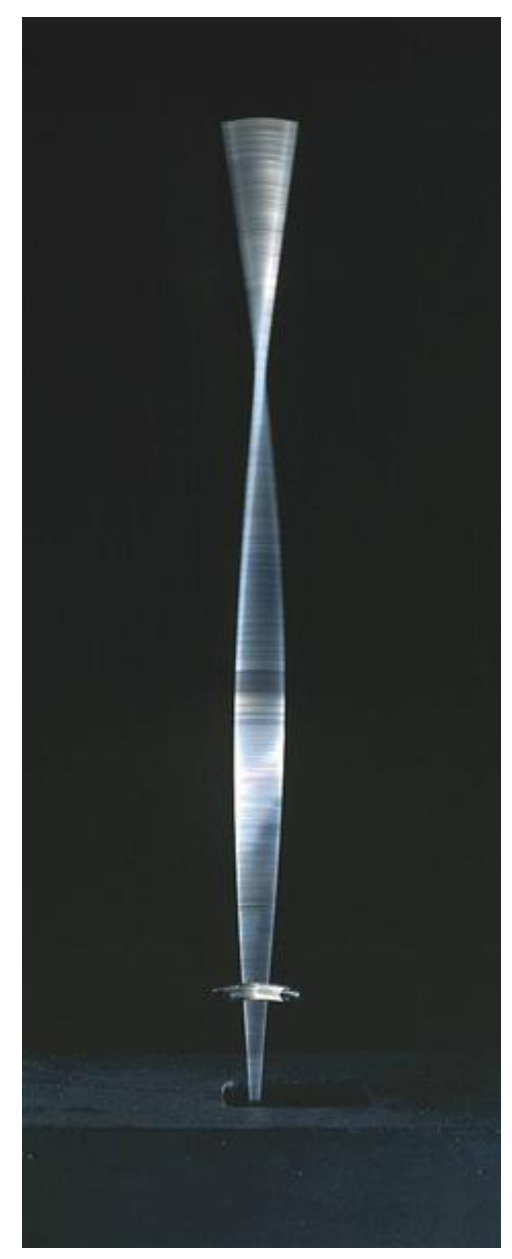

Görsel 12. Naum Gabo, Kinetik Kosntrüksiyon, Ahşap, Metal ve Elektrik motoru, 616 × $241 \times 190$ mm, 1919-1920, Tate Modern, Londra, Ingiltere 
Soyut sanat akımlarından biri olan Konstrüktivizm'in (İnşacılık) önde gelen sanatçılarından Naum Gabo "Gerçekçi Manifesto"da der ki: "Hiçbir yeni sanat sistemi, sanatın temeli yaşamın gerçek yasalarının üzerine dikilmeyene kadar, gelişen yeni bir kültürün baskısına karşı koyamayacaktır" (Art in Theory, 6 2005, s. 299). Yaşamın gerçek yasaları üzerine kurulu etkin, verimli varoluşun en yüksek güzellik olduğunu ve bu yasaların (fizik yasaları da denebilir) temelde soyut olduğunu söyler. Ancak "Eğer soyutlama serap ve kurgu üzerine inşa edilirse sanat bu yasalara karşı koyabilir mi?" (Sanat ve Kuram, 2011, s. 333) diye de sorar. Gabo'nun bu ifadelerinden de çıkarsayacağımız gibi sanattaki soyut anlayışın dayanağının yaşamın gerçek yasaları olması gerektiğidir. Uzay ve zaman'ı yaşamın üzerlerine bina edildiği yegâne formlar olarak görür ve bu nedenle sanat inşa edilmelidir der. Yani yaşamın içinde tezahür ettiği formların zaman ve mekân olduğunu söyler ve sanat için de en güçlü temellerin bunlar olduğunu ima eder. "Sanatta Konstrüktif Düşünce" adlı makalesinde Konstrüktivizm anlayışına dair açıklamalarda bulunur: [...] Sanat içindeki Konstrüktif düşüncenin temeli, Sanatın doğasına ve onun yaşam içindeki işlevlerine tümüyle yeni bir yaklaşımda yatar." dedikten sonra, Biçim ve İçerik ile ilgili yapılan genel ayırıma aykırı gelebilecek ifadelerde bulunur. ...Bu iki öğe Konstrüktif bakış açısından bir ve aynı şeydir. İçeriği Biçimden ayırmaz o -tersine, onların ayrı ve bağımsız varoluşunu mümkün görmez" (A.g.e., s. 420) diyerek sanatta gerçekleşmeyi de (sanat eseri - sanat faaliyeti) bir anlamda Aristocu bir anlayışla² ifade etmiş olduğu söylenebilir. Ancak konstrüktif düşünce bağlamında bunlardan birinin diğerine öncelikli olmadığını bunların aynı anda birlikte mevcudiyetlerinin olduğunu, aynı yönde ve aynı etkiyi üretmeleri gerekliliğinden söz eder.

Marcel Duchamp 20. yüzyıl'ın en önemli avangard (öncü) sanatçılarından biri olarak anılmaktadır. Onu Modern Sanat'ın ve Kavramsal Sanat'ın öncüsü olarak da gören sanatçılar ve sanat kuramcıları (teorisyenleri) bulunmaktadır. Örneğin Joseph Kosuth gibi.

Duchamp, "sanat eserleri" üretmekten öte, Ready-mades dediği hazıryapım nesneleri sanat bağlamında "kullanması" ile ve sanatı düşünsel-kavramsal bir mesele olarak yeniden gündeme getirmesi ile öne çıkmıştır. Sanatçı olarak ortaya koyduğu tavır ile sanatı biçimsel (biçimbilimsel) ve optik bir yaklaşımla (duyusal) 2 somut birleşik varlık olarak nesnelerin ancak madde ve form birlikteliğinden meydana geldikleri (varlık kazandıkları) 
değil, düşünsel (kavramsal) bir etkinlik alanı olarak söz konusu etmiştir.

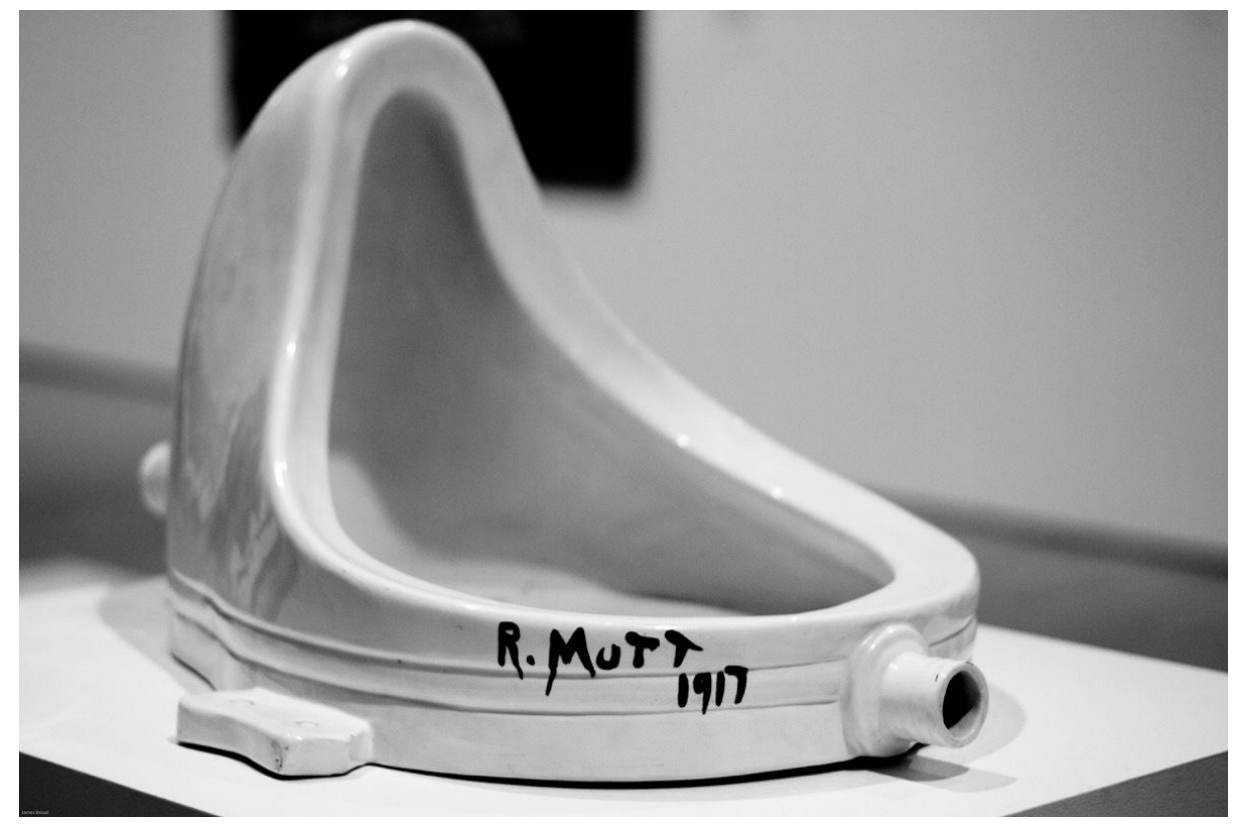

Görsel 13. Marcel Duchamp, Çeşme (The Fountain), 1917

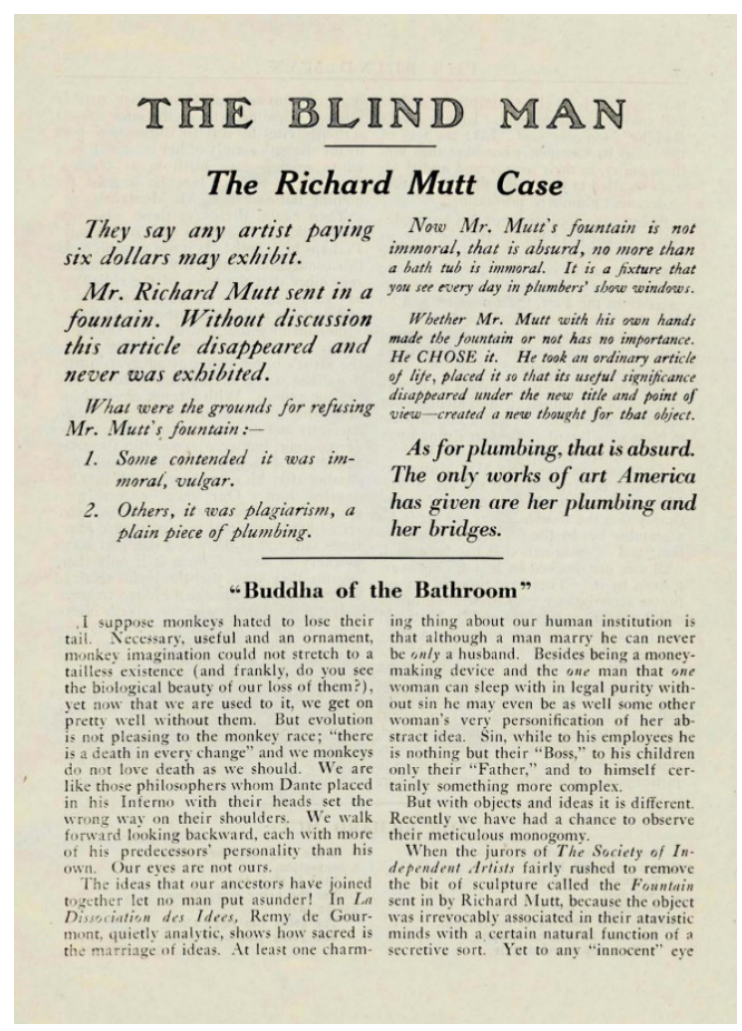

Görsel 14. The Richard Mutt Case, The Blind Man, No. 2, New York, 1917 


\section{"Richard Mutt Vakası" ("The Richard Mutt Case"), New York, 1917}

1917 yllında New York'ta bir sergi düzenlenir ve öncesinde sergi için altı dolar ödeyen herkesin sergiye katılabileceği söylenir. Duchamp da hazır-yapım bir pisuvarı alıp onu "adlandırıp" müstear bir isimle imzalayıp sergileme için gönderir. Ancak gönderilen "eser" perde arkası edilerek sergilenmez. Bunun üzerine bir yazı yayımlanır. The Blind Man'de Richard Mutt Vakası (The Richard Mutt Case) başlığı ile yayımlanan metinde: "Bay Mutt'ın çeşmeyi kendi eliyle yapıp yapmamasının bir önemi yok. O onu SEÇTi. Hayatın sıradan bir eşyasını aldı, onu, yeni adı ve bakış açısı altında, kullanım anlamının kaybolmasını sağlayacak şekilde yerleştirdi -o nesne için yeni bir düşünce yarattı." (The Richard Mutt Case, The Blind Man, No. 2, New York, 1917) ifadeleri yer almaktadır. Duchamp' a atfedilen metinde "seçme" terimi özellikle vurgulanmıştır. Ayrıca yeniden (farklı) adlandırma ve konumlandırma'ya dikkat çekilmektedir. Böylece sıradan bir hazır-yapım nesne de sanat bağlamı içine sokularak bir "sanat nesnesi"ne dönüşebilmekdir. Yani sanat ve sanat eseri sanatçının düşünsel çabası ve tavrı bağlamında söz konusu edilmektedir artık.

Duchamp, "sanat"ı, düşünsel (zihinsel) olarak söz konusu etmekle birlikte, sanatçıyı özel bir yaratıcı ve maddi metalar üreten kişi olarak görenlere, gösterenlere ve bu bağlamdaki ilişkilere karşı da tavır alır. Bu bağlamda bir "sanatçı" olmayı da reddeder. "Bugünkü anlamda sanatçı olmayı reddediyorum"; "Sanatçıya yönelik tutumları tamamen değiştirmek istedim"; "Son yüzyıl zarfında sanatçının dönüştüğü küçük tanrıyı öldürmek için çok çabaladım"; "Biliyorsunuz ki asla bir sanatçı olmak istemedim" (Lazzarato, M. 2017, s. 23).

Felsefeden Sonra Sanat (1969) adlı metinde, Joseph Kosuth (1945-) Marcel Duchamp'ı hem Modern Sanat için hem de sonrasındaki Kavramsal Sanat için asıl referans olarak gösterir. Sanatçı olmayı sanatın doğasını sorgulamaya bağlayan Kosuth bu bağlamda Duchamp'ı öne çıkarır.

...Katıksız Hazıryapımla (Readymades) birlikte, sanatın odak noktası dilin biçimi olmaktan çıkıp söylenen şey oldu. Yani sanatın doğasını bir morfoloji sorunu olmaktan çıkarıp bir işlev sorunu haline getirdi. Bu değişim -"görünüm" den "kavrayışa" olan değişim- "modern" sanatın başlangııı ve "kavramsal" sanatın başlangıcıydl. Bütün sanat (Duchamp'tan sonra) kavramsaldır (doğasında) çünkü sanat sadece kavramsal olarak var olur (Harrison, C. \& Wood, P., (Edt.), 2011). 


\section{$\operatorname{arts}=$}

"Sanatın doğası" söz konusu olduğunda "insanın doğası" da söz konusudur. Çünkü "sanatın doğası" "insan'ın mahiyeti (doğası)" ile doğrudan ilgilidir. Sanat ve Dada Üzerine Söyleşi'nin sonunda Duchamp'ın "sanat" üzerine olan ifadelerini de bu bağlamda değerlendirebiliriz:

Insanın insan olarak, hayvaniyet durumunun ötesine geçebildiği ve gerçek birey olarak kendini gösterdiği, yegane etkinlik biçiminin (formunun) sanat olduğuna inanıyorum. Cünkü sanat, zaman ve mekan ile yönetilemeyen bölgelere doğru çıkış yeridir. Yaşamak inanmaktır, bu benim inancımdır"3 (Marcel Duchamp, Interview on Art and Dada (1956), dk. 28:08 - 28:47).

\section{SONUÇ}

Modern sanatta öne çıkan tavır; katı natüralist anlayışın eleştirilmesi ve sanatın, dünyayı-olguları yansıtma-temsil etme ve bunun aracı olma iddiasının ötesine geçilerek, artık sanatçının özgür ve bağımsız bir "yaratım" veya ifade alanı olarak söz konusu edilmesidir.

Sanatçılardan bazıları doğanın ve yaşamın temelindeki soyut yasaları daha çok önemseyip bu soyut yasaların sanattaki yaratımda da temel olması gerektiğini ifade ederler. Başka bazıları da sanatın kaynağının dışsal değil de içsel yani ruhsal olması gerektiğini vurgularlar. Sanat'ın katı natüralist ve optik yaklaşımlardan arındıııması, saflaşması ve böylece bağımsız bir hale gelerek sanatçının saf yaratım (ifade) aracı haline gelmesi söz konusudur. Sonuçta daha soyut ve kavramsal yaklaşımlar sanatta öne çıkar. Sanatsal elemanların saf, soyut, zihinsel ve kavramsal ilişkiler bağlamında ele alınması düşüncesi ağır basar. Kübizm'in önde gelen sanatçılarından Braque, "nesnelere değil, bağıntılara inanıyorum" derken de bunu vurgulamaya çalışır. Bu bağlamda yapılan bir resim artık dış dünya ile ilişkili olup olmamasından öte, kendi içsel-yapısal bağıntıları bakımından değerlendirilir, yani saf formel (biçimsel) bağıntılar bakımından. Yani "Sanat eseri" analitik önermeler gibi kendi iç yapısı bakımından değerlendirilir ve sanat, adeta mantık ve matematik gibi formel bir alan olarak söz konusu edilir.

Modern sanatın sanatçıları Rönesans'tan beri süregelen katı figüratifnatüralist anlayışı terk ederek, sanatta daha soyut-matematiksel yaklaşımları öne çıkartmışlardır. Batıda sanatta öne çıkan bu yaklaşımlar sanat alanında devrimsel bir

3 Çev. Mehmet Şah MALTAŞ 
değişim ve dönüşümü meydana getirmiştir. Modern Sanat'taki soyut sanat anlayışı İslam sanatında da söz konusu olan soyut tavrı haliyle hatıra getirmektedir. Ancak İslam sanatındaki soyutlama ve soyut sanat anlayışı her ne kadar bazı yönlerden Modern sanattaki soyutlama ve soyut anlayışla benzerlikler taşısa da temelde bazı farklılıklar da söz konusu edilmektedir. Örneğin, Titus Burckhardt'ın İslam Sanatı adlı kitabında, Hüseyin Nasr' ın Sunuş'unda geçen ' 'Biri, bütünüyle beşeri ve rasyonalistik bir düzenin matematiksel bir soyutlamasına başvurarak on dokuzuncu yüzyıl Avrupa sanatının natüralistik ve donmuş formlarının çirkinliğinden kaçınmaya çalışır. Diğeri ise ruhani semadaki ilk örneklerde somut gerçekleri görür; ..." (Burckhard, 2013, s. 11) ifadeleri ve devamı gibi. İslam sanatında soyut-matematiksel yaklaşım ile ilgili, Hans Belting, Floransa ve Bağdat adlı eserinin İslam Sanatında Matematik ve Geometri adlı bölümünde şu ifadeler bulunur:

\begin{abstract}
Geometri, İbnü'l Heysem'in zamanında kendi başına, sanatta bir mesele haline (sanat haline) geldi, oysaki Rönesans sanatında geometri, duyular dünyasının konuları olan resimlerin temeline hizmet etti. Bundan dolayı İslam sanatında geometrinin tasvir edildiğini söyleyebiliriz; sadece bir teknik veya dekorasyon değil, kozmik yasaların bir temsili olarak da. Batı sanatının, canlı gibi resimler yapmanın veya temsilin bir metodu olarak tasarı (temsili) geometrisine tezat bir durumdur (Belting, 2011, s. 111).
\end{abstract}

İslam sanatında surete karşı olan tavır ve soyuta olan meyil, tüm bu değerlendirmelerle birlikte ve "dijital devrim" sonrası günümüzde tekrar üzerinde düşünülmesi gereken önemli bir meseledir.

Şeylerin gerçekliği veya "gerçeklik" söz konusu olduğunda dil, düşünce ve şeyler (olgular, nesneler) arasındaki ilişkiler de hep söz konusudur. Modern Sanatta bu ilişkilerin artık daha çok irdelendiği söylenebilir. Daha dilsel-mantıksal ve düşünsel yaklaşımlar önemsenir. Bu yaklaşımlar fiziksel-duyusal yaklaşımların ötesinde akıl ile "görülebilen"ler ve kavrananlar ile igilidir. Bundan dolayı daha metafiziksel bir tavrın öne çıktığı söylenebilir. Metafizik, maddi olan ve duyu organları ile duyumsanabilen alanın ardındaki dayanaklara, temel ilkelere yöneliktir. Ayrıca maddi olanların da manasına yönelme söz konusudur. Bu bağlamda, fizik bilimlerin, metafiziğe zemin oluşturduğu söylenebilir. Bu ilişkilerin sağlanması, insanın özsel bir niteliği olan ve onu diğer canlılardan (hayvanlardan) ayıran akıl yetisi sayesinde gerçekleşir. Akıl ise insanların hem sözlerinde (konuşmalarında) hem de eylemlerinde (icraatlarında) kendini "gösterir". Sanat da son derece kapsamlı bir insan etkiliği ve etkinlik alanı olarak insanın mahiyetine yöneliktir. Yani bir anlamda "insan olma" 


\section{$\operatorname{arts}=$}

etkinliğinin gerçekleştirildiği bir alandır denebilir. Bu etkinliğin sağlıklı bir şekilde gerçekleştirilebilmesi için de insanın kendi "benliğini" (ego) doğru tanıması esastır. Bu bağlamda Modern Sanatta, sanatçıların kendi zihin alanlarına ve benliklerine daha çok yöneldikleri ve "ellerindeki malzemeleri" de kendi sınılları ve imkanları doğrultusunda daha dilsel-zihinsel-ruhsal bir yönde kullanma çabası içine girdikleri söylenebilir.

\section{KAYNAKÇA}

Alberti, L. B. (1991). On Painting. (Trans. Cecil Grayson). England: Penguin Classics

Baudelaire, C. (2003). Modern Hayatın Ressamı (1. Baskı). (Çev. A. Berktay). İstanbul: Iletişim Yayınları

Belting, H. (2011). Florence and Baghdad. (Trans. D. L. Schneider). London: The Belknap Press of Harvard University Press.

Bernard, E. (2001). Cezanne Üzerine Anılar. (Çev. K. Özsezgin). Ankara: İmge Kitabevi Yayınları

Burckhardt, T. (2013). İslam Sanatı, Dil ve Anlam. (Çev. T. Koç). İstanbul: Klasik Yayınları.

Harrison, C. \& Wood, P. (Ed.). (2011). SANAT ve KURAM 1900-2000. (Çev. S. Gürses). İstanbul: Küre Yayınları.

Harrison, C. \& Wood, P. (Eds.) (2003). Art in Theory 1900-2000. Oxford: Blackwell Publishing.

Kandinsky, W. (2001). Sanatta Ruhsallık Üzerine (1.Baskı). (Çev. G. Ekinci). İstanbul: Altı Kırkbeş Yayın.

Lazzarato, M. (2017). Marcel Duchamp ve Işin Reddi. (Çev. S. Çalcı). Kolektif Kitap Yayınları.

Lynton, N. (1982). Modern Sanatın Öyküsü (1.Baskı). (Çev. C. Çapan \& S. Öziş). Remzi Kitabevi Yayınları.

Maltaş, M. Ş. (2019). Rönesansta, Matematik Içerikli Yeni Bir Sanat Bağlamında Doğrusal (Lınear) Perspektif. YYü. Sosyal Bilimler Enstitüsü Dergisi, 44, 223-238. http:// wWw.yyusbedergisi.com/dergi/ronesansta-matematik-icerikli-yeni-bir-sanatbaglaminda-dogrusal-linear-perspektif20190717045915.pdf 
Marcel Duchamp Interview on Art and Dada (1956)) https://www.youtube. com/watch? v=DzwADsrOEJk

Moszynska, A. (2004). Abstract Art. London: Thames \& Hudson World of Art.

"Sanat Tanımı Topluluğu, Çalışma 3" (Aralık 1997) İstanbul: STT Yayını.

Ponty, M. M. (2006) Göz ve Tin. (Çev A. Soysal). İstanbul: Metis Yayınları.

The Richard Mutt Case, The Blind Man, No. 2, New York, 1917 https:// monoskop.org/images/6/6f/The_Blind_Man_2_May_1917.pdf

The Timaeus of Plato, (1888) R.A. ARCHER HIND, M.A., London, Macmillan and Co. and New York 